\title{
Comment
}

\section{SEARCH AND SEIZURE: A REVIEW OF THE CASES SINCE PEOPLE v. CAHAN}

In 1955 the Supreme Court of California in People v. Cahan ${ }^{1}$ reversed a longstanding California rule. when it held inadmissible evidence illegally obtained. ${ }^{2}$ This holding precipitated immediate and serious problems of law enforcement inasmuch as prior law had not developed a body of rules to guide police in obtaining evidence under the restrictions of the exclusionary rule. This Comment will examine a number of the post-Cahan decisions for the "workable rules" fashioned by the courts as they pertain to (a) consent, (b) arrest and searcli warrants, and (c) arrest without a warrant. ${ }^{4}$

\section{Consent by Defendant}

\section{CONSENT}

Consent presents relatively few legal problems; ${ }^{5}$ but the factual determination of consent is frequently litigated. If the prosecution can establisli consent, it is not necessary to show that the search and seizure was reasonable, that it was incident to arrest, or that the officers had a valid warrant for search or arrest." Consent need not be formal; it may be casually given. Thus where the defendant says, "No, go ahead," in response to an officer's request to look around, consent has been given. ${ }^{7}$ And when the defendant says, "You are the boss," meaning, as

144 Cal. 2d 434, 282 P.2d 905 (1955). See Comment, The Cahan Case: The Interpretation and Operation of the Exclusionary Rule in California, 4 U.C.L.A.L. REv. 252 (1957). The discussion includes both procedural aspects of the rule and the law of arrest, search, and scizure, with a somewhat different organization and emphasis. It concludes that the post-Cahan decisions are "consistent with the policy of deterring illegal police methods and promoting justice." Id. at 270 .

2 Before the adoption of the exclusionary rule in Cahan illegal methods of obtaining evidence did not bar its admission. Irvine v. California, 347 U.S. 128 (1954); People v. Kendall, 111 Cal. App. 2d 204, 244 P.2d 418 (1952) ; People v. Channell, 107 Cal. App. 2d 192, 236 P.2d 654 (1951).

3 See 44 Cal. $2 \mathrm{~d}$ at 451,282 P.2d at 915.

4 There will be no attempt to discuss the specific problems of the use of electronic devices in securing evidence. See, e.g., People v. Malotte, 46 Cal. 2d 59, 292 P.2d 517 (1956), 44 Cadaf. L. Rev. 780 (1956) ; People v. Tarantino, 45 Cal. 2d 590, 290 P.2d 505 (1955) ; People v. Ander. son, 145 A.C.A. 247, 302 P.2d 358 (1956); People v. Graff, 144 A.C.A. 203, 300 P.2d 837 (1956) ; People v. Avas, 144 A.C.A. 90, 300 P.2d 695 (1956).

Nor will the policy considerations of the desirability of the exclusionary rule be discussed. See Barrett, Exchusion of Evidence Obtained by Illegal Searches-A Comment on People vs. Cahan, 43 CALTr. L. REv. 565 (1955).

Procedural problems are discussed only incidentally. See generally People v. Kitchens, 46 Cal. 2d 260, 294 P.2d 17 (1956) (in pre-Cahan cases the objection may be raised for the first time on appeal); People v. Beard, 46 Cal. 2d 278, 294 P.2d 29 (1956) (the objection can be raised for the first time upon a motion for a new trial); Hatjis v. Superior Court, 144 A.C.A. 479, 301 P.2d 44 (1956) (post-Cahan case; failure to object raises presumption that arrest, search, and seizure were lawful) ; People v. Superior Court, 137 Cal. App. 2d 194, 289 P.2d 813 (1955) (objection can be raised at preliminary hearing or upon trial); People v. Farrara, $46 \mathrm{Cal}$. 2d 265, 294 P.2d 21 (1956) (defendant makes a prima facie case by showing arrest was made without a warrant, or that private premises were entered or a search made without a search warrant).

5 Since a parolee is still under supervision, he may not claim the constitutional guaranty against unauthorized entry; hence it is immaterial whether or not he consents. People v. Denne, 141 Cal. App. 2d 499, 297 P.2d 451 (1956).

6 People v. Burke, 47 A.C. 39, 301 P.2d 241 (1956).

7 Ibid. 
both defendant and officer understand, that defendant is agreeing to a search, this casual affirmance is sufficient consent to justify a search. ${ }^{8}$

However, the objection that consent was not in fact given, or freely given, may be raised by the defendant. ${ }^{9}$ The burden is upon the prosecution to prove consent, but the defendant may overcome this by proving intimidation or coercion. Intimidation or coercion is a fact question to be determined in each case. ${ }^{10}$ The fact that defendant was taken in handcuffs to his home is not sufficient to establish coercion; ${ }^{11}$ nor is coercion proved simply because the defendant was in jail at the time he consented to the search. ${ }^{12}$

\section{Consent by a Third Party}

It is also clearly established that consent may be given by someone other than the defendant. ${ }^{13}$ Those who have a joint right of control over the premises with the defendant may give such consent.14 Thus when a police officer calls at defendant's home and requests permission to search the premises, defendant's wife may give consent to the search. ${ }^{16}$ Also, defendant's mother may consent to the search. ${ }^{16}$ However, the mere fact that an occupant accompanies an officer making a search of a house does not establish consent. ${ }^{17}$

Furthermore, one who mistakenly, but in good faith, believes he has a right of joint control over the premises may consent to a search of the premises by the police. Thus in People v. Gorg ${ }^{18}$ defendant gave his consent to a search of lis apartment, which was located over a garage on Stevens' property. ${ }^{10}$ This search was unavailing. Later Stevens entered the apartment to clean it and, discovering a potted plant ${ }^{20}$ in the bathroom, removed the plant to a service porcll. Police officers, having obtaimed a "rap sheet" indicating defendant's prior arrest for possession of narcotics, returned to defendant's apartment, whereupon Stevens authorized the officers to enter and requested them to search the defendant's apartment. In this second search police seized the plant and other evidence later identified as marijuana. Defendant Gorg objected that he had not consented to the second

8 People v. Garnett, 148 A.C.A. 275, 306 P.2d 571 (1957).

9 People v. Burke, 47 A.C. 39, 301 P.2d 241 (1956).

10 Ibid. The prosecution must present evidence that consent was in fact given. People v. Jennings, 142 Cal. App. 2d 160, 298 P.2d 56 (1956). When the defendant denies consent or alleges coercion, the burden is upon him to overcome the prosecution's showing of consent and establish facts showing he was intimidated or coerced. Badillo v. Superior Court, $46 \mathrm{Cal}$. 2d 269, 294 P.2d 23 (1956).

11 People v. Lujan, 141 Cal. App. 2d 143, 296 P.2d 93 (1956).

12 People v. Gorg, 45 Cal. 2d 776, 291 P.2d 469 (1955).

13 Ibid.; People v. Michael, 45 Cal. 2d 751, 290 P.2d 852 (1955); People v. Dominguez, 144 A.C.A. 63, 300 P.2d 194 (1956); People v. Stewart, 144 A.C.A. 651, 301 P.2d 301 (1956); People v. Silva, 140 Cal. App. 2d 791, 295 P.2d 942 (1956).

14 People v. Dominguez, 144 A.C.A. 63, 300 P.2d 194 (1956).

16 Ibid.

16 People v. Michael, 45 Cal. 2d 751, 290 P.2d 852 (1956). Logically, this rule would extend to all adult members of the household. It is not clear that this is true with respect to premises occupied by partners. See Stein v. United States, 166 F.2d 851 (9th Cir. 1948).

17 People v. Jennings, 142 Cal. App. 2d 160, 298 P.2d 56 (1956).

1845 Cal. 2d 776, 291 P.2d 469 (1955).

10 In People v. Gorg, sutra note 18, defendant's status as tenant, guest, or servant was not clear; therefore Stevens might reasonably mistake his authority to enter. But People v. Roberts, 47 A.C. 379,303 P.2d 721 (1956), was distinguished in that defendant was clearly a tenant; therefore, there could be no reasonable reliance on the landlord's purported authority since in fact she had none. The conviction was sustained on other grounds.

20 It was not clear whether Stevens was aware that the potted plant was inarijuana. 
search. The court held that the officers were justified under the circumstances in concluding that Stevens in fact had the authority he purported to have and that the officers' entry and search was not unreasonable.

It is clear, therefore, that in the absence of coercion or intimidation, the prosecution need not show that the search and seizure was reasonable, was incident to a lawful arrest, or that it was based on a valid warrant if consent to search has been given.

\section{WARRANTS OF SEARCH AND ARREST}

The Cahifornia constitution ${ }^{21}$ provides that no search warrant shall issue "but on probable cause, supported by oath or affirmation, particularly describing the place to be searched and the persons and things to be seized." Additional requirements for the issue of search warrants are imposed by the California Penal Code. ${ }^{22}$ To the law enforcement official, these requirements present serious practical difficulties, especially in regard to narcotics and bookmaking activities. Not only is there the frequent impossibibity of describing with particularity the evidence to be seized, ${ }^{23}$ but the time element, especially in narcotics cases, may be crucial. As one authority has pointed out, "As a matter of practice, ... . search warrants are seldom used by the police."24

California courts have not been oblivious to these practical considerations. Since the constitutional guaranty is interpreted as one against unreasonable search, ${ }^{25}$ the test is said to be whether the search was reasonable, not whether it was reasonable to procure a search warrant. ${ }^{28}$ Thus even where there is reasonable time to obtain a warrant, the search may be justified without one on the ground that it was incident to a valid arrest under section 836 of the Penal Code or under a warrant of arrest. ${ }^{27}$

Nevertheless, problems still arise with respect to search warrants. Suppose that upon a search incident to a valid search warrant, goods other than those particularly described therein are discovered. May they also be seized? This problem was raised in People $v$. Acosta ${ }^{28}$ where an officer armed with a warrant describing the goods sought as "leroin and other paraphernalia" discovered during his search not only the goods described but also a quantity of marijuana. The district court of appeal held that discovery of the heroin and other paraphernalia justified an arrest for possession of all narcotics. Initial entry is authorized by the warrant; when the goods described therein are found, the arrest is authorized, which, in turn, justifies seizure of other contraband.

21 Car. Const. art. I, § 19.

22 Section 1524 provides grounds for issuance, including, " 1 . When the property was stolen or embezzled .... 2. When it was used as the means of committing a felony ... 3. When it is in the possession of any person with the intent to use it as a means of committing a public offiense ...."

Section 1525 states: "A search warrant cannot be issued but upon probable cause, supported by affidavit, naming or describing the person, and particularly describing the property and the place to be searched." Section 1526 provides that the magistrate, before issumg tho warrant, must examine on oath the complainant and any witnesses he may produce.

23 See CaI. PEN. Code $\$ 1525$.

24 Barrett, Exclision of Evidence Obtained by Illegal Searches-A Comment on People vs. Cahan, 43 CAIIF. L. REv. 565, 570 (1955).

25 See People v. Cahan, 44 Cal. 2d 434, 438, 282 P.2d 905, 907 (1955).

20 United States v. Rabinowitz, 339 U.S. 56 (1950).

27 People v. Winston, 46 Cal. 2 d 151, 293 P.2d 40 (1956) ; People v. Sayles, 140 Cal. App. $2 d$ 657,295 P.2d 579 (1956).

28142 Cal. App. 2d 59, 298 P.2d 29 (1956). 
If the goods described in the warrant are not found, but other contraband is, it can be lawfully seized. But it is not certain whether property which is only evidentiary can be taken. ${ }^{29}$

Will the fact that a warrant is defective in some respect render seizure of contraband illegal? It would seem that a warrant describing the things to be seized simply as "narcotics," for example, lacks the specificity required by California Penal Code section $1525 .^{30}$ An entry under authority of such a warrant, or one deficient in other respects, would be unlawful; hence the evidence seized would be inadmissible. However, the fact that the warrant is based on what is technically hearsay information will not render the warrant invalid provided the affiant shows reasonable grounds for belief of the facts asserted..$^{31}$

\section{SEARCH INCIDENT TO ARREST WITHOUT A WARRANT}

California Penal Code Sections 836 (1), (3), (5)

In view of the limited use of search warrants and since consent to a search is the exception rather than the rule, the great majority of cases arising simce Cahan have involved the problem of search incident to arrest under section 836 , which authorizes arrest without a warrant in prescribed situations. The theory is that if a person can be arrested for the commission of an offense, the officer can search the person and premises for things used in the commission of that offense. ${ }^{32}$ Thus where there is a valid arrest under section 836, a search and seizure incident to the arres $^{33}$ is not unreasonable though made without a warrant.

Section 836 provides that:

A peace-officer may ... without a warrant, arrest a person:

1. For a public offense committed or attempted in lis presence.

....

29 The existence of a valid warrant or the defendant's consent authorizes the officers' entry. Having made lawful entry they might properly seize any contraband used in the commission of an offense. People v. Acosta, 142 Cal. App. 2d 59, 298 P.2d 29 (1956); In re Dixon, 41 Cal. 2d 756, 264 P.2d 513 (1953).

However, a lawful entry is not authority for a general ransacking of the premises. "An arrest may not be used as a pretext to conduct a general search of one's premises for incriminating evidence, and it has been repeatedly said that where the right to conduct a search is obtained ostensibly for one purpose it may not be used in reality for another." People v. Roberts, 47 A.C. $379,383,303$ P.2d 721, 723 (1956). The Roberts court cited several United States Supreme Court cases which distinguished contraband and property which is merely evidentiary. The former includes "the instrumentalities and means by which a crime is committed, the fruits of crime such as stolen property, weapons . . . and property the possession of which is a crime." Harris v. Umited States, 331 U.S. 145, 154 (1947); accord, United States v. Lefkowitz, 285 U.S. 452 (1932); Gouled v. United States, 255 U.S. 298 (1921); Weeks v. United States, 232 U.S. 383 (1914); cf. People v. Mills, 148 A.C.A. 415, 306 P.2d 1005 (1957).

30 People v. Acosta, 142 Cal. App. 2d 59, 298 P.2d 29 (1956).

31 Ibid. Contra, Umited States v. Goodwin, 1 F.2d 36 (S.D. Cal. 1924).

32 But the scope of the search is not limited merely to such items. For example. Car. Pex. CODE $\$ 846$ authorizes "any person Inaking an arrest may take fron the person arrested all offensive weapons which he may have about his person ...." This is necessary for the protection of the arresting officer. And if during the searcl for the suspected contraband and weapons the officers encounter other contraband it would be unreasonable to assume that they must "blind themselves to what was in plain sight simply because it was disconnected with the purpose for which they entered." People v. Roberts, 47 A.C. 379, 384, 303 P.2d 721, 723 (1956).

33 The search may be made before or after the arrest. People v. Boyles, 45 Cal. 2d 652, 290 P.2d 535 (1955); People v. Sayles, 140 Cal. App. 2d 657, 295 P.2d 579 (1956). 
3. When a felony has in fact been committed, and he bas reasonable cause for believing the person arrested to have committed it. felony.

5. At night, where there is reasonable cause to believe that he has committed a

Subsection (1) refers to a "public offense," whereas the remaining subsections refer to a "felony." If a valid arrest is authority for a search, it would seem that under the hiteral wording of subsection (1) the officer could make a search any time he makes an arrest for an offense committed or attempted in his presence. However, the courts have mterpreted subsection (1) to mean that the search will be considered reasonable only where it bears some relation to the crime alleged. The offense must justify the search. A ininor traffic violation such as double parking, ${ }^{34}$ or an illegal left turn, ${ }^{35}$ or illegally blocking a roadway ${ }^{36}$ will not justify a search.

On the other hand, drunken or erratic driving, ${ }^{37}$ driving in a manner indicating that the person may be under the influence of narcotics, ${ }^{88}$ or flight from the office $^{39}$ will justify a search of the auto and the occupants. These and similar offenses in themselves provide reasonable cause for behef that a felony is being committed; hence arrest is authorized under 836 (3) or (5) and search incident to the arrest is reasonable.

People v. Blodgett 40 is illustrative. Officers observed two persons in a cab double parked in front of an Oakland hotel at 3:00 a.m. The officers investigated, and the suspicious behavior of one of the passengers when ordered out of the car prompted a search of the vehicle. Marijuana was found stuffed behind the back seat. The evidence was held admissible, the court remarking that although an arrest for double parking alone would not justify a search, ${ }^{41}$ questioning people who are abroad at late hours is reasonable, and when their actions are "furtive," a search is justified.

Again, in People v. Martin ${ }^{42}$ officers observed two men in a parked car in an area known as a "lover's lane." When the officers turned their car around to investigate, the two men fled. They were overtaken, and a search revealed a quantity of marijuana. The California Supreme Court held the search and seizure reasonable. The mere fact of two men in a parked automobile on a lover's lane at night was reasonable cause for investigation, the court said. This, coupled with flight, justified arrest and search. ${ }^{43}$

In a third decision, People v. Martin, ${ }^{44}$ police noted a car blocking an access road to a beach, in violation of California Vehicle Code sections 582 and 583. The officers stopped to examine the car and because of the driver's efforts to conceal something on the floor of the car, made a search. What appeared to be particles of

\footnotetext{
84 See People v. Blodgett, 46 Cal. 2d 114, 293 P.2d 57 (1956).

85 People v. Molarius, 146 A.C.A. 143, 303 P.2d 350 (1956).

36 See People v. Martin, 140 Cal. App. 2d 387, 295 P.2d 33 (1956).

87 People v. Johnson, 139 Cal. App. 2d 663, 294 P.2d 189 (1956).

38 People v. Lujan, 141 Cal. App. 2d 143, 296 P.2d 93 (1956).

30 People v. Martin, 46 Cal. 2d 106, 293 P.2d 52 (1956).

4046 Cal. 2d 114, 293 P.2d 57 (1956).

41 The search would bear no relation to the offense.

4246 Cal. 2d 106, 293 P.2d 52 (1956).

48 Id. at 108, 293 P.2d at 53. Justice Carter dissented, saying he believed this to be an unwarranted extension of the term "reasonable cause."

44140 Cal. App. 2d 387, 295 P.2d 33 (1956).
} 
marijuana were observed on the front of the defendant's shirt. ${ }^{45}$ Defendant's conviction for possession of marijuana ${ }^{46}$ was upheld by the district court of appeal against his contention that the evidence was inadmissible because it was the result of an unlawful search. The court said that the violation of the Vehicle Code section justified the officers "looking into the matter," and the presence of marijuana constituted probable cause to beheve that a felony was being committed. The defendant's attempt to conceal something and the appearance of marijuana permitted an inference that a felony had been committed, thereby justifying an arrest and search.

In Martin and Blodgett the search was justified not on the theory that an arrest was made for an offense committed in the officer's presence (subsection (1)), but on the ground the officer had reasonable cause to believe a felony had been committed by the person arrested (subsection (3)). If such an arrest is valid, search incident to arrest is reasonable. Therefore, if the offense which will support a search does not fall within subsection (1), the inquiry becomes one of reasonable cause to make the arrest under subsection (3).

\section{Reasonable Cause}

"Reasonable cause" has been defined as "such a state of facts as would lead a man of ordinary care and prudence to believe, or entertain an honest, strong suspicion, that the person in question is guilty of a crime."47 "Probable cause," which is used interchangeably with "reasonable cause," is "a suspicion founded upon circumstances sufficiently strong to warrant a reasonable man in the belief that the charge is true." 48

Inasinuch as reasonable or probable cause is a factual problem, ${ }^{40}$ in effect, "in each ... case the courts will be forced first to try the policeman ...." to establish the validity of the arrest.51 When the defendant's objection to the admissibility of the evidence is founded upon his contention that the arrest was without probable cause, the prosecution must show that the officer did have reasonable cause to make the arrest. Where the prosecution fails to do so, the arrest will not be valid, and the search, no matter what is turned up in the way of contraband or incriminating evidence, will be regarded as unreasonable. ${ }^{52}$

Where the record is silent and there is no evidence of any illegality, the court is willing to presume that the officers regularly and lawfully performed their duties. ${ }^{53}$

45 The officer demonstrated exceptional perception since only upon laboratory analysis were the particles proved to be marijuana.

46 See Cal. Health \& Safety Code $\$ 11500$.

47 People v. Woods, 139 Cal. App. 2d 515, 523, 293 P.2d 901, 907 (1956).

48 Id. at 524, 293 P.2d at 907.

40 People v. Boyles, 45 Cal. 2d 652, 290 P.2d 535 (1956) ; People v. Woods, 139 Cal. App. 2d 515, 293 P.2d 901 (1956).

50 Barrett, Exclusion of Evidence Obtained by Illegal Searches-A Comment on People vs. Cahan, 43 Caxir. L. Rev. 565, 589 (1955).

51 The California Supreme Court has indicated concern with the delays that result. In Badillo v. Superior Court, 46 Cal. 2d 269, 294 P.2d 23 (1956), it was held error for the trial court to grant a motion to set aside the imformation under CAL. PEN. Code $\$ 995$. The court stated that if there is any substantial evidence or applicable presumption to support a denial of the motion, the ultimate decision on admissibility should be made at the trial on the basis of all the evidence bearmg on the issue. See also Rogers v. Superior Court, 46 Cal. 2d 3, 291 P.2d 929 (1955); People v. Soto, 144 A.C.A. 318, 301 P.2d 45 (1956).

52 People v. Brown, 45 Cal. 2d 640, 290 P.2d 528 (1955).

E3 Hatjis v. Superior Court, 144 A.C.A. 479, 301 P.2d 44 (1956). 
"There is no established formula for the determination of reasonableness. Each case is to be decided on its own facts and circumstances." illustrate what the courts consider reasonable cause for arrest. Reasonable cause has been found where police had acted on information from one who had previously furnished rehable information ${ }^{55}$ or where they had acted on information from a paid or anonymous informant and there were other circumstances tending to support the information..$^{56}$ Reasonable cause existed when the officer recognized the defendant, previously known to the officer as a "user," and the defendant was at the wheel of an automobile, apparently under the influence of narcotics. ${ }^{.7}$

In People v. Rodriguez ${ }^{58}$ officers patrolling an area known to be frequented by narcotics "pushers" stopped defendant for questioning and were apparently satisfied with his answers until they noticed a piece of newspaper protruding from his trouser cuff. They recalled him and upon further investigation found heroin capsules wrapped in the newspaper. His conviction was upheld, the court reasoning that the officers were justified in questioning a person upon the streets at night. And on the particular facts it was reasonable to infer that a felony was being committed; therefore reasonable cause to inake the arrest existed.

Where officers in an apartment building at night recognized the odor of opium, they had reasonable cause to suspect that a felony was being committed and were justified in entering defendant's apartment to make a search. ${ }^{59}$ Similarly, where officers called at the suspect's home and observed when he answered the door that he was under the influence of a narcotic, they had reasonable cause to enter and search inasmuch as a felony was being committed in their presence. ${ }^{60}$ Also where officers watching through the window of defendant's home saw a copy of a newspaper devoted exclusively to horse racing news, several scratch pads, and defendant answering the telephone and making notes, they had reasonable cause to enter and make an arrest and seize the evidence. ${ }^{01}$

On the other hand, reasonable cause is not established by the mere fact that defendant was a suspect, ${ }^{62}$ or that defendant was known to police as a book-

54 People v. Woods, 139 Cal. App. 2d 515, 525, 293 P.2d 901, 908 (1956).

55 People v. Gonzales, 141 Cal. App. 2d 604, 297 P.2d 50 (1956); People v. Vance, 138 Cal. App. 2d 871, 292 P.2d 552 (1956).

56 Willson v. Superior Court, 46 Cal. 2 d 291, 294 P.2d 36 (1956); People v. Sayles, 140 Cal. App. 2d 657, 295 P.2d 579 (1956).

57 People v. Lujan, 141 Cal. App. 2d 143, 296 P.2d 93 (1956).

58140 Cal. App. 2d 865, 296 P.2d 38 (1956).

59 People v. Bock Leung Chew, 142 Cal. App. 2d 400, 298 P.2d 118 (1956).

60 People v. Mendoza, 145 A.C.A. 348, 302 P.2d 340 (1956). It would seem that the arrest would have been justified here under CAI. PEN. CODE $\$ 836(1)$. The result is the same where defendant, obviously under the influence of narcotics, answered the door of an apartment in which he was visiting. People v. Soto, 144 A.C.A. 318, 301 P.2d 45 (1956).

61 People v. Moore, 140 Cal. App. 2d 870, 295 P.2d 969 (1956). This is in interesting contrast to People v. Sanders, 46 Cal. 2d 247, 294 P.2d 10 (1956), where police officers observed defendant, known to them as a bookmaker, in his business establishment (a music store) with telephone and several scratch pads. They had arrested a person leaving the place the day before. They entered and seized the paraphernalia, and the court held the evidence inadinissible on the ground there was no reasonable cause to believe a felony was being committed. The case may be explained as a failure of the prosecution to present evidence substantiating their belief that a felony was being committed since the court remarked that reasonable cause could have been shown by the arrest the previous day or by evidence that the premises were being used by a bookmaker.

62 People v. Harvey, 142 Cal. App. 2 d 728, 299 P.2d 310 (1956). 
maker. ${ }^{63}$ Association with known narcotics offenders, where there was no prior information that defendant had been involved, was not sufficient in People v. Schraier. ${ }^{64}$ But in People v. Hickman, ${ }^{65}$ where the defendant was actually in the company of a known offender, the court found reasonable cause for arrest and the fruits of a search of defendant were admissible.

Information from an anonymous tipster or from one who has not previously provided reliable information to the police is not in itself reasonable cause for arrest. ${ }^{\circ B}$ Nor is defendant's presence on the street at a late lour of inght justification for arrest and search where the officer has no reasonable cause to believe an offense is being committed in his presence. ${ }^{67}$ Furthermore, the inere possibility that cars crossing the Mexican border might be carrying contraband is not sufficient cause. ${ }^{88}$

\section{California Penal Code Section 836(2)}

Subsection (2) authorizes arrest without a warrant "when a person arrested has committed a felony although not in his [the officer's] presence." Will an arrest under subsection (2) support a search incident to the arrest? Suppose that reasonable cause for arrest is lacking and no apparent offense is being committed in the officer's presence, but narcotics are discovered in defendant's possession. A felony obviously has been committed. Is the search reasonable in the absence of reasonable cause to make the arrest?

Subsection (2) has received little mention in the cases, ${ }^{69}$ principally because the prosecution has generally relied on subsections (3) and (5), and so the precise meaning of subsection (2) has never been squarely faced. In two recent Califorma Supreme Court cases $^{70}$ it lias been discussed, but disagreement among members of the court leaves the exact construction of subsection (2) uncertain.

In People v. Brown ${ }^{71}$ police officers seized defendant on a street, identified themselves, and asked to see what she had in her hand. She refused and the officers took froin her a sinall container of heroin. The prosecution contended the search was incident to a lawful arrest under subsection (2), and if the arrest was lawful, search was reasonable, regardless of probable cause. The state's contention was rejected and the evidence was lield inadmissible. Justice Traynor, writing for the majority, found it umecessary to determine the precise meaning of subsection (2) and whether it impliedly requires reasonable cause for an arrest. ${ }^{72}$ The question, the court said, was not whether the arrest was lawful in the absence of reasonable cause, but whether the search incident to arrest was reasonable. Lawful or not, the arrest was clearly unreasonable if the officer had no reasonable cause to believe

03 People v. Sanders, 46 Cal. 2d 247, 294 P.2d 10 (1956).

64141 Cal. App. 2d 600, 297 P.2d 81 (1956).

65143 Cal. App. 2d 79, 299 P.2d 389 (1956).

60 Willson v. Superior Court, 46 Cal. 2d 291, 294 P.2d 39 (1956); People v. Thymialsas, 140 Cal. App. 2d 940, 296 P.2d 4 (1956).

67 People v. Simon, 45 Cal. 2d 645, 290 P.2d 531 (1955).

68 People v. Gale, 46 Cal. 2d 253, 294 P.2d 13 (1956).

69 See Comment, The Cahan Case: The Exclusionary Rule and the Law of Search, Seizure, and Arrest in California, 3 U.C.L.A. L. Rev. 55 (1955).

70 People v. Brown, 45 Cal. 2d 640, 290 P.2d 528 (1956); Badillo v. Superior Court, 46 Cal. 2d 269, 294 P.2d 23 (1956).

7145 Cal. 2 d 640, 290 P.2d 528 (1956).

72 "This question would be presented directly if a guilty felon sued an officer for false arrest on the ground that the officer had no reasonable cause to believe him guilty ... or sought to justify resisting arrest on the same ground." Id. at $643 \mathrm{n} .1,290$ P.2d at 530 n.1. 
the defendant guilty; and a search incident to such arrest can be no more reasonable than the arrest. "To accept the Attorney General's contention [that subsection (2) does not require reasonable cause] would defeat the purpose of the constitutional provisions prohibiting unreasonable searches and seizures and destroy the efficacy of the exclusionary rule in many felony prosecutions."78

Justice Spence disagreed with the majority in Brown and elaborated in his dissent in Badillo v. Superior Court, ${ }^{74}$ the other case discussing subsection (2). There he poimted out that the requirement of reasonable cause appears in subsections $(3),(4)$, and (5) but that the plain language of subsection (2) requires no reasonable cause. To impute such is to "render it meaningness and purposeless."75 $\mathrm{He}$ concluded that an arrest without a warrant is a lawful arrest if the person has in fact committed a felony, whether or not the arresting officer acted upon reasonable cause. He interpreted Brown as requiring not only a lawful arrest but a "reasonable arrest," a wholly new element in the law of arrest.

In the light of Brown, subsection (2) seems to have been rendered innocuous, if not meaningless. From a practical standpoint the prosecution generally will be able to show the probable cause required by subsections (3) and (5); but when a felony has been committed and probable cause cannot be shown, the defendant will go free under the Brown case. ${ }^{76}$

In summary, section 836 authorizes arrest without warrant in five situations. Not all arrests will support a general search. If a search is justified it must, as is the case with search warrants, be reasonable; and it may be made before or after the arrest.

Although subsection (1) permits arrest for offenses committed or attempted in the officer's prsence, the search will be reasonable only if it bears some relation to the crime alleged. Subsections (3) and (5) require reasonable or probable cause. When an arrest is made under subsection (1) and the offense does not warrant a search, additional incriminating circumstances may constitute probable cause, thereby justifying a search under subsections (3) or (5).

On its face, subsection (2) allows arrest without probable cause when a felony has in fact been committed, but apparently a search incident to arrest without reasonable cause is illegal under the Brown decision.

\section{CONCLUSION}

To a large extent the appellate courts have fulfilled the supreme court's mandate for the formulation of workable rules pertaining to searches and seizures and the issuance of warrants. In the two years since Cahan the law has been clarified with respect to search based on consent and on warrants. With respect to search incident to arrest, no hard and fast rules seem possible since in most cases the validity of the arrest, and thus the reasonableness of the search, depends upon the existence of reasonable cause, a question of fact. It is obvious that litigation will continue for some time to come as to what is "reasonable."

Warren G. Reid*

7345 Cal. 2d 640, 644, 290 P.2d 528, 530 (1956).

7446 Cal. 2d 269, 294 P.2d 23 (1956).

75 $1 d$. at 274, 275, 294 P.2d 26 (dissent).

78 "We were fully aware that in its immediate operation the exclusionary rule would permit guilty persons to escape punishment, but were convinced that it was necessary to secure respect by law enforcement agencies of constitutional guarantees." People v. Brown, 45 Cal. 2d 640, 644, 290 P.2d 528, 531 (1955).

* Member, Third-Year Class. 